Review

\title{
Vascular Endothelial Growth Factor-Delivery Systems for Cardiac Repair: An Overview
}

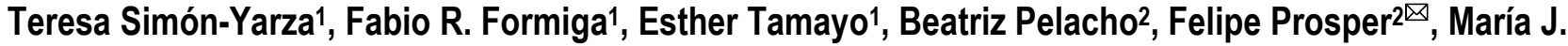 \\ Blanco-Prieto ${ }^{1 凶}$
}

1. Pharmacy and Pharmaceutical Technology Department, School of Pharmacy, University of Navarra, Pamplona, Spain;

2. Hematology Service and Area of Cell Therapy, Clínica Universidad de Navarra, Foundation for Applied Medical Research, University of Navarra, Pamplona, Spain.

Corresponding author: Maria J. Blanco-Prieto, Department of Pharmacy and Pharmaceutical Technology, School of Pharmacy, University of Navarra, Irunlarrea 1, E-31080 Pamplona, Spain. Tel.: +34 948425600 x 6519 ; fax: +34 948425649 e-mail: mjblanco@unav.es, and Felipe Prosper, Hematology and Cell Therapy, Clínica Universidad de Navarra, Av. Pío XII 36, Pamplona 31008, Spain. Phone +34 948255400 Fax +34 948 296500. E-mail: fprosper@unav.es

(C) Ivyspring International Publisher. This is an open-access article distributed under the terms of the Creative Commons License (http://creativecommons.org/ licenses/by-nc-nd/3.0/). Reproduction is permitted for personal, noncommercial use, provided that the article is in whole, unmodified, and properly cited.

Received: 2011.10.21; Accepted: 2011.12.23; Published: 2012.06.04

\begin{abstract}
Since the discovery of the Vascular Endothelial Growth Factor (VEGF) and its leading role in the angiogenic process, this has been seen as a promising molecule for promoting neovascularization in the infarcted heart. However, even though several clinical trials were initiated, no therapeutic effects were observed, due in part to the short half life of this factor when administered directly to the tissue. In this context, drug delivery systems appear to offer a promising strategy to overcome limitations in clinical trials of VEGF.

The aim of this paper is to review the principal drug delivery systems that have been developed to administer VEGF in cardiovascular disease. Studies published in the last 5 years are reviewed and the main features of these systems are explained. The tissue engineering concept is introduced as a therapeutic alternative that holds promise for the near future.
\end{abstract}

Key words: VEGF, protein delivery, cardiovascular disease, angiogenesis, tissue engineering.

\section{VEGF}

\section{Discovery}

Vascular Endothelial Growth Factor (VEGF) was first isolated and purified from the medium conditioned by bovine pituitary folliculo-stellate cells by Henzel and Ferrara [1]. The newly discovered heparin-binding factor induced proliferation of vascular endothelial cells (ECs), showing no effects on corneal ECs. This apparent target cell selectivity induced the authors to name it "at least provisionally" VEGF $[1,2]$.

Some months later Ferrara et al [2] published a study in which they demonstrated that VEGF was a secreted protein. Interestingly, they screened cDNA and isolated clones encoding mature monomers of 121, 165 and 189 amino acids. At the same time Keck et al published the purification of the Vascular Permeability Factor [3], identified 5 years before by Senger et al [4]. Surprisingly, this protein was identical to VEGF 189.

Since that moment a considerable volume of research has been carried out, and it is now known that the VEGF 121 isoform is the most diffusible [5]. Two mechanisms by which this protein is released into a soluble form, namely alternative splicing and proteolytic cleavage, have been described, in vivo pro-angiogenic activity has been tested, several tyrosine kinase VEGF receptors are now known, and an 
increasing number of molecular studies on VEGF is being published [6].

\section{Biological aspects}

Research focusing on the VEGF family has led to the discovery of several members encoded by different genes: VEGF-A or Vascular Permeability Factor (firstly discovered), B, C, D, E, F and PlGF (Platelet Growth Factor)[6, 7]. The most widely studied member of the family as far as angiogenesis is concerned has been VEGF-A, which we will refer to as VEGF from now on. Different VEGF isoforms from alternative splicing have been described: $\mathrm{VEGF}_{121}, 145,165,189$ and 206 (number indicates amino acid residues). $V_{E G F}{ }_{121}$ is the freely diffusible form, $\mathrm{VEGF}_{145}$ remains bound to cell surface and extracellular matrix (ECM) and $\mathrm{VEGF}_{189}$ and $\mathrm{VEGF}_{206}$ are sequestered in the cell surface and ECM [5, 7]. Regarding its different role in neovascularization, briefly, VEGF $_{121}$ is a mitogenic agent and a chemo-attractant for endothelial cells (ECs) during angiogenesis and vasculogenesis. VEGF $_{165}$ is a soluble heparin binding protein, and is thus less diffusible than VEGF ${ }_{121}$, but it exhibits higher mitogenic activity. On the other hand VEGF 145 induces EC proliferation and angiogenesis in vivo [5].

From the beginning, researchers realized the clinical relevance of those factors implicated in the angiogenic process. In fact, the role of anti-angiogenic strategies to treat human cancer was proposed by Folkman in 1971, 18 years before VEGF was discovered [8]. On the other hand, pro-angiogenic activity also appeared promising as an innovative therapeutic approach in ischemic disorders such as myocardial ischemia. As VEGF is a secreted protein with EC selective activity it was proposed from the first moment as a promising means of regulating angiogenesis.

\section{VEGF in anti-angiogenic therapy}

Only 4 years were necessary to develop a successful strategy against human cancer based on VEGF's known involvement in vasculogenesis. The proof of this concept was carried out by Ferrara's group [9]. They administered an anti-VEGF monoclonal antibody into nude mice that had been previously injected with different human tumor cell lines. The treatment was successful in inhibiting tumor growth. This effect was associated with a diminished vessel density in the treated tumors. Studies continued and in 1997 the first humanized anti-VEGF monoclonal antibody was developed. Approved in 2004 by the Food and Drug Administration (FDA) for its use in patients with previously untreated metastatic colorectal carcinoma, this antibody, named Bevacizumab [10], is nowadays used in several diseases, namely breast cancer and macular degeneration, among others.

Another strategy that has been explored is the use of small molecule VEGF receptor tyrosine kinase inhibitors. In 2005 Sorafenib received the FDA approval for its use in patients with advanced renal cell carcinoma [11]. In 2007 approval was extended for the treatment of patients with unresectable hepatocellular carcinoma. In the meantime, in 2006 another molecule with the same mechanism (Sunitinib malate) was approved for the treatment of advanced (metastatic) renal cell carcinoma and for the treatment of gastrointestinal stromal tumor after disease progression, or intolerance to the treatment of choice [12].

\section{VEGF in pro-angiogenic therapy}

To study the role of VEGF in the formation of new vasculature it is important to identify different processes in vessel formation [13]. Vasculogenesis takes place during mammalian embryo development. It consists of the formation of de novo vessels by differentiation of angioblasts into ECs. Sprouting during angiogenesis is the subsequent process, which ensures the expansion of the vessel network. Arteriogenesis involves the covering of EC channels by pericytes or vascular smooth muscle cells. Besides these steps, other mechanisms can occur, such as intussusception of pre-existing vessels or recruitment of bone marrow derived cells and endothelial progenitor cells that are incorporated into the endothelial lining in a process known as postnatal vasculogenesis [14]. In all these processes, VEGF is present and plays a critical role [15].

In the adult organism, quiescent vessels are constituted by quiescent ECs and pericytes. These suppress EC proliferation and release cell survival signals like VEGF. When a hypoxic stimulus activates quiescent vessels, pericytes are detached from the vessel wall. Matrix metalloproteinases (MMPs) start proteolytic degradation and pericytes are released from the basement membrane; ECs lose their junctions, allowing vessels to dilate. VEGF acts at this point by increasing the permeability of the EC layer, and plasma protein flows out establishing an ECM scaffold. Following integrin signaling, ECs migrate onto this ECM surface. Angiogenic mediators of the ECM such as VEGF and fibroblast growth factor (FGF) are released by proteinases. These factors are implicated in the constitution of the ECM as an appropriate angiogenic environment. After these steps, a cell is selected to lead vessel enlargement. VEGF gradient, regulated by soluble and matrix bound isoforms, makes tip cells upregulate delta-like ligand 4 (DLL4) expression, activating $\mathrm{NOTCH}$ in stalk cells, then downregulating 
VEGF receptors. As a consequence, stalk cells are less responsive to VEGF, helping the tip cells to take the lead. Tip cells respond to stimuli and move towards the angiogenic signal. Stalk cells, on the other hand, elongate the stalk by division and establish the vessel lumen [14].

The complexity of this vasculogenic process has not always been as clear as it is now, but the importance of VEGF in the neovascularization process has been evident since it was first discovered. In the last two decades, research to find a VEGF-based therapy to treat tissues damaged due to hypoxia has concluded in various clinical trials. In the next section, an overview of the clinical trials performed in the context of cardiovascular repair will be discussed.

\section{Clinical trials with VEGF: results and conclu- sions}

The results of small phase I trials using intracoronary and intravenous infusions of VEGF in patients with coronary artery disease were encouraging [16-18]. For example, Hendel et al.[17] conducted a study with 14 patients who underwent exercise and myocardial perfusion measurements before as well as 30 and 60 days after VEGF administration. Although it was not designed to demonstrate VEGF efficacy, the study showed a significant improvement in exercise capacity without any safety issues. Also, the resting nuclear myocardial perfusion scans indicated a VEGF treatment effect. In another small study, a dose escalation trial was designed to determine the safety and tolerability of intracoronary VEGF infusions in 15 patients with underperfused myocardium. As a result, myocardial perfusion imaging was improved in 7 out of 14 patients at 60 days and all 7 patients with follow-up angiograms had improvements in the collateral density score. This study also established that VEGF can safely and tolerably be administered to humans by intracoronary infusion for up to 20 minutes at $0.050 \mu \mathrm{g} / \mathrm{kg} / \mathrm{min}$ [19]. In a study employing intravenous administration of VEGF in 28 patients, the authors reported evidence of improvement in rest myocardial perfusion and in collateral density [16]. In spite of the promising results of these small phase I trials, a randomized, double-blind, placebo-controlled phase II trial failed to show differences between the VEGF and placebo groups. The VIVA (Vascular endothelial growth factor in Ischemia for Vascular Angiogenesis) study compared two doses of VEGF to placebo in 178 patients with coronary artery disease. A single intracoronary infusion followed by three separate intravenous infusions was given. Despite the safety and tolerability, the administration regimes revealed that VEGF offered no improvement beyond placebo by day 60, although high-dose VEGF resulted in better improvement in angina and favorable trends in exercise treadmill test time and angina frequency, by day 120 [20].

The results of myocardial clinical trials using VEGF delivery have generally been disappointing and the studies have failed to consistently demonstrate improvements in treated patients as compared with placebo. Many of these trials relied on an intravenous infusion or intracoronary delivery of the recombinant protein. It is noteworthy that VEGF is not effective when delivered intravenously [21]. Therefore, these negative results have been attributed, at least partially, to the short-lived effect and high instability of the protein when injected as a bolus. Intravenous administration of VEGF is limited by its short in vivo half life ( $30 \mathrm{~min})$ and overall dose is limited by off-target site toxicity issues [18]. In the case of myocardial ischemia, the amount of VEGF localized in the ischemic region after systemic administration is minimal and does not persist for more than 1 day [22]. Based on these issues, some unusual characteristics of the VIVA trial make interpretation of therapeutic efficacy of VEGF somewhat difficult; in particular, suboptimal dose or route of administration and uncontrolled delivery method of VEGF. Perhaps the most striking contribution of the VIVA trial was to consider that more preclinical data were needed with regard to the time course of angiogenesis and the optimal dose and route of administration to induce effective VEGF therapy in the myocardium. Also, given that the low recovery in the myocardium of the administered VEGF might be another important cause of the missing clinical effect, local and sustained VEGF delivery by controlled release approaches in the heart tissue might be a better strategy to achieve higher efficacy in VEGF-based therapy for myocardial ischemia. Table 1 summarizes the main clinical trials using VEGF recombinant protein for cardiac repair.

\section{DELIVERY SYSTEMS}

\section{Protein delivery systems}

When administering drugs to an organism, the goal is to reach the appropriate dose at the site of action for the necessary period of time, so that the drug acts in its optimal condition, with the minimum adverse effects. Drug delivery systems (DDS) are designed taking into account the specificities of the drug to be administered, the organism in which it is administered and the disease being treated. Depending on these conditions, release profiles are designed and materials and device architecture are chosen. Even though the concept of drug delivery is relatively old, 
its application to biomolecules, such as proteins, hormones, antibodies or genes, has been explored only in the last $15-20$ years.

Table I. Clinical trials using VEGF recombinant proteins for cardiac repair.

\begin{tabular}{|c|c|c|c|}
\hline Route & Trial $\mathrm{n}$ & Outcomes & Reference \\
\hline Intracoronary & $\begin{array}{l}\text { Phase } 14 \\
\text { I }\end{array}$ & $\begin{array}{l}\text { Some improvement in perfu- } \\
\text { sion in patients treated with } \\
\text { low-dose VEGF; five of six } \\
\text { patients had perfusion im- } \\
\text { provement at rest and stress } \\
\text { at higher doses }\end{array}$ & [17] \\
\hline Intracoronary & $\begin{array}{l}\text { Phase } 15 \\
\text { I }\end{array}$ & $\begin{array}{l}\text { Dose screening study; well } \\
\text { tolerated up to } 0.05 \\
\mathrm{mg} / \mathrm{kg} / \mathrm{min} \text {; myocardial } \\
\text { perfusion imaging was im- } \\
\text { proved in } 7 \text { out of } 14 \text { patients } \\
\text { at } 60 \text { days }\end{array}$ & [18] \\
\hline Intravenous & $\begin{array}{l}\text { Phase } 28 \\
\text { I }\end{array}$ & $\begin{array}{l}\text { An increase in exercise ca- } \\
\text { pacity was reported without } \\
\text { any safety issues }\end{array}$ & [16] \\
\hline $\begin{array}{l}\text { Intracoronary/ } \\
\text { intravenous }\end{array}$ & $\begin{array}{l}\text { Phase } 178 \\
\text { II }\end{array}$ & $\begin{array}{l}\text { VIVA study; safe and well } \\
\text { tolerated; no improvement } \\
\text { beyond placebo in all meas- } \\
\text { urements by day } 60 \text {. By day } \\
\text { 120, high-dose VEGF result- } \\
\text { ed in significant improve- } \\
\text { ment in angina; no im- } \\
\text { provements in myocardial } \\
\text { perfusion }\end{array}$ & [20] \\
\hline
\end{tabular}

As scientists make progress in their understanding of the mechanisms of disease, there is increasing awareness that protein delivery is a very attractive approach in many diseases. In our context, as clinical trials have highlighted, promoting angiogenesis via growth factors (GFs) or cytokines demands the use of a DDS that preserves their properties and prolongs their short half life [23]. Proteins are labile systems with primary, secondary, tertiary and quaternary structures. Primary structure relates to the amino acid sequence, whereas higher structures refer to protein fold. Chemical instability is due to modification at the first level, such as deamidation, oxidation, beta elimination, incorrect disulfide formation or racemization. Physical instability refers to secondary, tertiary and quaternary structure, with phenomena like denaturation, aggregation, precipitation and surface adsorption. All these instability issues result in the short half life of VEGF when administered directly in the tissue. Incorporating VEGF in an adequate carrier serves to protect it until it is released from the device. However, incorporating VEGF, and any protein, in an adequate carrier poses unique difficulties due to physical and chemical instability. Temperature,
$\mathrm{pH}$, pressure, the presence of metal ions and denaturing agents like surfactants need to be tightly controlled during the manufacturing process to avoid chemical instability.

The first marketed protein included in a DDS was the luteinizing hormone releasing hormone (LHRH), which was commercialized by Astra Zeneca as Zoladex, with FDA approval in 1989 for the treatment of prostate cancer. It was a $1.5 \mathrm{~mm}$ sized subcutaneous implant prepared with the copolymer polylactide-co-glycolide (PLGA). Nowadays other protein formulations have come on the market: long release octreotide (Octreotide ${ }^{\circledR}$ LAR ${ }^{\circledR}$, Novartis Pharmaceuticals), human growth hormone (Nutropin depot ${ }^{\circledR}$, Genentech), adenosin deaminase (Adagen ${ }^{\circledR}$, Enzon), L-asparaginase (Oncaspar ${ }^{\circledR}$, Enzon), Interferon- $\alpha 2$ (Pegasys ${ }^{\circledR}$, Roche) as examples.

\section{VEGF delivery systems in cardiac repair}

To achieve sustained presence of VEGF in the damaged tissue, both gene therapy and DDS have been designed. However, the aim of this review is focused on the second option. Updated information about gene therapy in this field can be found in the bibliography [24-27].

Studies published in the last five years related to VEGF delivery systems and cardiovascular diseases have been reviewed. Those corresponding to the last two years are summarized in Table 2. During this period of time, two systems have been the most widely employed: scaffolds and particulated constructs, represented in Figure 1.

\section{Scaffolds}

Most authors propose the use of scaffolds as delivery platforms. In general, the requirements that scaffolds must fulfill are several [28]: adequate 3D architecture with the desired shape, volume and mechanical strength; highly porous structure to allow tissue growth and diffusion of biomolecules; biocompability; appropriate degradation rate; and good interface adherence so that proteins attach in a desired way to the material. Particularly, basic physical requirements for myocardial engineered constructs are robust yet flexible mechanical properties, contractile ability, and electrophysiological stability $[28,29]$. The physical and biochemical effects of scaffolds in cardiovascular differentiation have been reviewed elsewhere [30]. Moreover, a scaffold designed for protein delivery needs to show high loading capacity, homogenous protein distribution, a protein binding affinity that allows adequate protein release and, importantly, ability to maintain protein stability and bioactivity. 


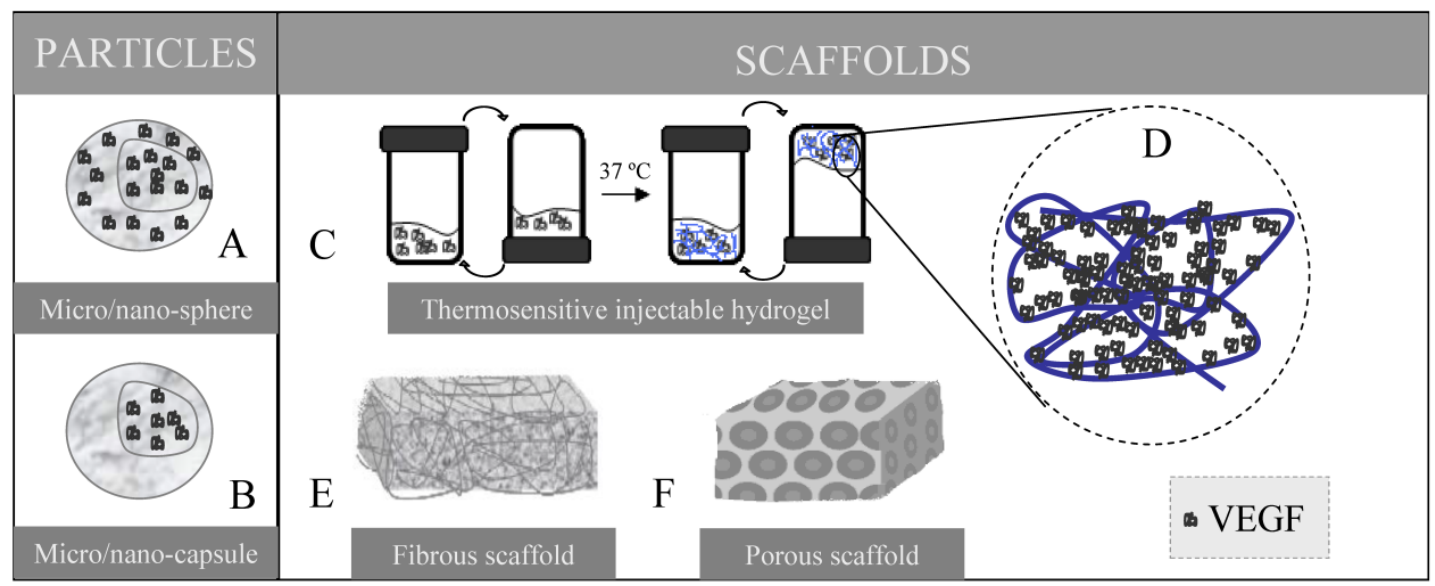

Figure I. The main DDSs employed in recent years in the field of VEGF and cardiac repair are represented. In the particles (nano or microsized) VEGF can be included homogenously through the entire particle (A) or only in the core of the system (B), which affects the release profile. A wide variety of scaffolds has been designed. In a thermosensitive injectable hydrogel (C) at temperatures under $37^{\circ} \mathrm{C}$ the blend of the vehicle and the VEGF remains liquid, but when it is injected and reaches the body temperature the mixture solidifies and VEGF is entrapped within the gel matrix (D). By electrospinning fibrous scaffolds are built up (E) whereas porous scaffolds $(F)$ can be formed by solvent casting and particulate leaching method.

Table 2. Summary of VEGF delivery and cardiac repair in the last 2 years.

\begin{tabular}{|c|c|c|c|c|c|c|c|}
\hline & DDS & COMPOSITION & $\begin{array}{l}\text { ANGIO } \\
\text { GENIC } \\
\text { FACTO } \\
\text { R/S }\end{array}$ & $\begin{array}{l}\text { PREPARATION } \\
\text { METHOD }\end{array}$ & $\begin{array}{l}\text { ANGIOGNENIC } \\
\text { EFFICACY } \\
\text { ASSAY }\end{array}$ & AUTHOR'S CONCLUSION & REF. \\
\hline & $\begin{array}{l}\text { surface cross- } \\
\text { linked Heparin }\end{array}$ & polycaprolactone & VEGF & $\begin{array}{l}\text { Solvent casting and } \\
\text { particulate leaching } \\
\text { method }\end{array}$ & $\begin{array}{l}\text { Subcutaneous } \\
\text { implant model in } \\
\text { mice }\end{array}$ & $\begin{array}{l}\text { Modification of the scaffold with } \\
\text { heparin improves VEGF efficacy }\end{array}$ & [37] \\
\hline & $\begin{array}{l}\text { hollow-fiber } \\
\text { membrane }\end{array}$ & cellulose acetate & $\begin{array}{l}\text { VEGF \& } \\
\text { S1P }\end{array}$ & $\begin{array}{l}\text { Double injection } \\
\text { extrusion/ precipi- } \\
\text { tation method }\end{array}$ & $\begin{array}{l}\text { Subcutaneous } \\
\text { implant model in } \\
\text { mice }\end{array}$ & $\begin{array}{l}\text { System capable of exploring sequen- } \\
\text { tial delivery of angiogenic factors. } \\
\text { Sequential delivery of VEGF followed } \\
\text { by S1P resulted in recruitment of } \\
\text { more ECs and higher maturation } \\
\text { index }\end{array}$ & [43] \\
\hline & $\begin{array}{l}\text { biomimetic hy- } \\
\text { drogel (adhesion } \\
\text { peptide se- } \\
\text { quence RGDS) }\end{array}$ & PEG diacrylate & VEGF & $\begin{array}{l}\text { Photopolymeriza- } \\
\text { tion }\end{array}$ & $\begin{array}{l}\text { In vitro (HUVECs } \\
\text { and } h M E C s)\end{array}$ & $\begin{array}{l}\text { The system promotes EC prolifera- } \\
\text { tion, migration and viability mainte- } \\
\text { nance }\end{array}$ & [44] \\
\hline & $\begin{array}{l}\text { patch with co- } \\
\text { valently immo- } \\
\text { bilized VEGF }\end{array}$ & collagen & VEGF & Commercial scaffold & $\begin{array}{l}\text { Right ventricular } \\
\text { free wall resection } \\
\text { and replacement } \\
\text { with the scaffold }\end{array}$ & $\begin{array}{l}\text { Collagen scaffold with covalently } \\
\text { immobilized VEGF improved tissue } \\
\text { formation }\end{array}$ & [32] \\
\hline & $\begin{array}{l}\text { hydrogel with } \\
\text { surface cross- } \\
\text { linked Heparin }\end{array}$ & star-PEG & $\begin{array}{l}\text { VEGF \& } \\
\text { FGF-2 }\end{array}$ & Cross linking & $\begin{array}{l}\text { In vitro (HUVECs) } \\
\text { and Chicken cho- } \\
\text { rioallantoin mem- } \\
\text { brane angiogéne- } \\
\text { sis assay }\end{array}$ & $\begin{array}{l}\text { Angiogenic activity superior to the } \\
\text { administration of single factors }\end{array}$ & $\begin{array}{l}{[45,} \\
46]\end{array}$ \\
\hline & hydrogel & alginate & VEGF & Cross linking & $\begin{array}{l}\text { Hindlimb ische- } \\
\text { mia in mice }\end{array}$ & & [47] \\
\hline 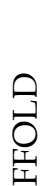 & $\begin{array}{l}\text { covalently im- } \\
\text { mobilized fac- } \\
\text { tors }\end{array}$ & collagen & $\begin{array}{l}\text { VEGF \& } \\
\text { Ang-1 }\end{array}$ & Commercial scaffold & $\begin{array}{l}\text { Chicken } \\
\text { chorioallantoin } \\
\text { membrane } \\
\text { angiogenesis assay }\end{array}$ & $\begin{array}{l}\text { Scaffolds with co-immobilized VEGF } \\
\text { and Ang-1 further improved angio- } \\
\text { genesis as compared to inde- } \\
\text { pendently immobilized VEGF or } \\
\text { Ang-1 }\end{array}$ & [31] \\
\hline$\bigcup_{\circlearrowleft}^{\mathbb{4}}$ & $\begin{array}{l}\text { composite } \\
\text { scaffold }\end{array}$ & $\begin{array}{l}\text { Poly(ether)uretha } \\
\text { ne-polydimethylsi }\end{array}$ & $\begin{array}{l}\text { VEGF \& } \\
\text { bFGF }\end{array}$ & $\begin{array}{l}\text { Spray-phase } \\
\text { inversion method }\end{array}$ & $\begin{array}{l}\text { Subcutaneous } \\
\text { implant and uni- }\end{array}$ & $\begin{array}{l}\text { Incorporation of VEGF, bFGF and } \\
\text { heparin in the composite scaffold }\end{array}$ & [38] \\
\hline
\end{tabular}




\begin{tabular}{|c|c|c|c|c|c|c|c|}
\hline & & $\begin{array}{l}\text { loxane } \\
\text {-fibrin }\end{array}$ & & & $\begin{array}{l}\text { lateral hind limb } \\
\text { ischemia model in } \\
\text { rat }\end{array}$ & enhances angiogenesis & \\
\hline & $\begin{array}{l}\text { temperature } \\
\text { sensitive in- } \\
\text { jectable hydro- } \\
\text { gel }\end{array}$ & PVL-b-PEG-b-PVL & VEGF & $\begin{array}{l}\text { Metal-free cationic } \\
\text { method }\end{array}$ & $\begin{array}{l}\text { Myocardial infarc- } \\
\text { tion rat model } \\
\text { (coronary artery } \\
\text { ligation) }\end{array}$ & $\begin{array}{l}\text { The system preserved ventricular } \\
\text { function by stabilizing the infarct and } \\
\text { reducing angiogenesis }\end{array}$ & [41] \\
\hline & $\begin{array}{l}\text { fibrous mem- } \\
\text { branes }\end{array}$ & Dextran/PLGA & VEGF & $\begin{array}{l}\text { Coaxial electrospin- } \\
\text { ning }\end{array}$ & In vitro & $\begin{array}{l}\text { The system positively promotes cell } \\
\text { proliferation }\end{array}$ & [48] \\
\hline & $\begin{array}{l}\text { dual layered } \\
\text { scaffold com- } \\
\text { bined with an } \\
\text { osmotic release } \\
\text { mechanism }\end{array}$ & $\begin{array}{l}\text { Poly(trimethylene } \\
\text { carbonate) }\end{array}$ & $\begin{array}{l}\text { VEGF \& } \\
\text { HGF }\end{array}$ & Cross linking & In vitro (HAECs) & $\begin{array}{l}\text { System able to release combined GFs } \\
\text { at similar rates, and at controllable } \\
\text { sequences }\end{array}$ & [49] \\
\hline \multirow{6}{*}{ 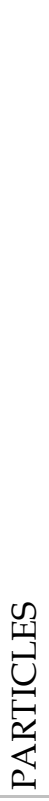 } & \multirow[t]{3}{*}{ NPs } & $\begin{array}{l}\text { Hyaluronic ac- } \\
\text { id/chitosan }\end{array}$ & $\begin{array}{l}\text { VEGF \& } \\
\text { PDGF-B } \\
\text { B }\end{array}$ & $\begin{array}{l}\text { Ionic gelification } \\
\text { technique }\end{array}$ & - & $\begin{array}{l}\text { NPs entrap efficiently both factors. } \\
\text { PDGF-BB is released in a sustained } \\
\text { manner over } 1 \text { week and VEGF } \\
\text { within the first } 24 \text { hours. }\end{array}$ & [50] \\
\hline & & $\begin{array}{l}\text { PLGA/heparin/fi } \\
\text { brin }\end{array}$ & VEGF & $\begin{array}{l}\text { Spontaneous emul- } \\
\text { sion solvent diffu- } \\
\text { sion method }\end{array}$ & $\begin{array}{l}\text { Rabbit ischemic } \\
\text { hind limb }\end{array}$ & $\begin{array}{l}\text { The system strongly increases the in } \\
\text { vivo therapeutic angiogenic effects of } \\
\text { VEGF }\end{array}$ & [51] \\
\hline & & PLGA & VEGF & $\begin{array}{l}\text { Modification of the } \\
\text { double emulsion } \\
\text { method }\end{array}$ & $\begin{array}{l}\text { Hindlimb ische- } \\
\text { mia in mice }\end{array}$ & $\begin{array}{l}\text { Feasibility of the system } \\
\text { to produce a more viogorous revas- } \\
\text { cularization when compared with } \\
\text { free VEGF administration }\end{array}$ & [52] \\
\hline & \multirow[t]{3}{*}{ MPs } & PLGA & VEGF & $\begin{array}{l}\text { Double emul- } \\
\text { sion/solvent evap- } \\
\text { oration method }\end{array}$ & In vitro (HUVECs) & $\begin{array}{l}\text { The system allows VEGF encapsula- } \\
\text { tion and bioactive protein release up } \\
\text { to } 21 \text { days }\end{array}$ & [53] \\
\hline & & PLGA & VEGF & $\begin{array}{l}\text { Double emul- } \\
\text { sion/solvent evap- } \\
\text { oration method }\end{array}$ & $\begin{array}{l}\text { Myocardial infarc- } \\
\text { tion rat model } \\
\text { (coronary artery } \\
\text { ligation) }\end{array}$ & & [54] \\
\hline & & Collagen & VEGF & Cross linking & In vitro (HUVECs) & $\begin{array}{l}\text { The system allows VEGF encapsula- } \\
\text { tion and bioactive protein release up } \\
\text { to } 4 \text { weeks }\end{array}$ & [55] \\
\hline \multirow{3}{*}{ 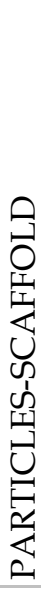 } & $\begin{array}{l}\text { MPs } \\
\text { MPs-Scaffold }\end{array}$ & $\begin{array}{l}\text { PLGA } \\
\text { (MPs)PLGA-N-me } \\
\text { thyl pyrrolidone } \\
\text { (scaffold) }\end{array}$ & VEGF & $\begin{array}{l}\text { MPs: spray dry } \\
\text { Scaffold: gelification }\end{array}$ & $\begin{array}{l}\text { Murine model of } \\
\text { peripheral angio- } \\
\text { genesis }\end{array}$ & $\begin{array}{l}\text { Both formulations provide a method } \\
\text { to incite neovascularization from a } \\
\text { single injection }\end{array}$ & [56] \\
\hline & $\begin{array}{l}\text { NPs } \\
\text { Scaffolds (hy- } \\
\text { drogel or poly- } \\
\text { meric) } \\
\text { NPs-Scaffold } \\
\text { (hydrogel or } \\
\text { polymeric) }\end{array}$ & $\begin{array}{l}\text { NPs: Dex- } \\
\text { tran-sulfate/chitos } \\
\text { an } \\
\text { Scaffold: Mat- } \\
\text { rigel® or PLGA }\end{array}$ & VEGF & $\begin{array}{l}\text { NPs: complex for- } \\
\text { mation and coacer- } \\
\text { vation } \\
\text { Scaffold: gas foam- } \\
\text { ing/particulate } \\
\text { leaching method } \\
\text { (Matrigel@: com- } \\
\text { mercially obtained) }\end{array}$ & $\begin{array}{l}\text { Subcutaneous } \\
\text { injection } \\
\text { (NPs-Matrigel }{ }^{\circledR} \text { ) } \\
\text { NPs-PLGA scaf- } \\
\text { folds implanted } \\
\text { into the intraperi- } \\
\text { oneal fat pad of } \\
\text { mice }\end{array}$ & $\begin{array}{l}\text { Angiogenesis was clearly improved } \\
\text { by VEGF encapsulation and further } \\
\text { incorporation into implants, com- } \\
\text { pared to direct VEGF incorporation } \\
\text { into implants }\end{array}$ & [57] \\
\hline & $\begin{array}{l}\text { MPs-Scaffold } \\
\text { co-administered } \\
\text { with ECs }\end{array}$ & $\begin{array}{l}\text { Alginate MPs } \\
\text { colla- } \\
\text { gen/fibronectin } \\
\text { gel }\end{array}$ & $\begin{array}{l}\text { VEGF \& } \\
\text { MCP-1 }\end{array}$ & Cross linking & $\begin{array}{l}\text { Subcutaneous } \\
\text { implant model in } \\
\text { mice }\end{array}$ & $\begin{array}{l}\text { Delivery of multiple therapeutic pro- } \\
\text { teins to enhance the efficacy of } \\
\text { cell-based vascularization }\end{array}$ & [58] \\
\hline \multirow[b]{2}{*}{ 釭 } & $\begin{array}{l}\text { Polymeric } \\
\text { injectable carrier }\end{array}$ & $\begin{array}{l}\text { Poly(trimethylene } \\
\text { carbonate) }\end{array}$ & VEGF & - & $\begin{array}{l}\text { Subcutaneous } \\
\text { injection in rat }\end{array}$ & $\begin{array}{l}\text { The approach has potential for } \\
\text { providing effective, local, bioactive } \\
\text { growth factor delivery. }\end{array}$ & [59] \\
\hline & $\begin{array}{l}\text { Collagen patch- } \\
\text { es }\end{array}$ & Collagen & VEGF & $\begin{array}{l}\text { Collagen binding } \\
\text { domain is fused to } \\
\text { VEGF }\end{array}$ & $\begin{array}{l}\text { Myocardial im- } \\
\text { plantation }\end{array}$ & $\begin{array}{l}\text { Patches improve left ventricular car- } \\
\text { diac function and increase the vascu- } \\
\text { lar density }\end{array}$ & {$[60]$} \\
\hline
\end{tabular}


These devices can be constructed with natural or synthetic biomaterials. In the past the use of non-degradable constructs involved a second intervention to extract these. Nowadays the use of biodegradable devices is almost presupposed. Components found in the ECM are preferably from within the range of natural materials: collagen, fibrinogen, hyaluronic acid (HA), chitosan, alginate, etc. The use of these natural scaffolds has increased during recent years and companies have already put them on the market. In the last two years, Radisic et al have published two papers in which they immobilize VEGF in a commercial ultrafoam [31, 32], demonstrating that the system has suitable mechanical properties for potential use in repairing heart defects and that it improves angiogenesis both in vitro [31] and in vivo, in a rat heart injury model [32]. Because of their natural origin, most of these components are biocompatible, bioactive and tend to show similar mechanical properties to the native tissue. However, synthetic materials have been developed with optimal qualities for tissue regeneration. Elastomeric scaffolds such as poly (glycolic acid) (PGA) and poly (lactid acid) (PLA), as well as their copolymer PLGA, have been successfully applied [33-35]. Like natural materials, polyesters are biocompatible and biodegradable, and by controlling polymerization it is possible to modulate their mechanical properties. In fact, PLGA has already received FDA approval for its use in drug delivery [36] Also polyanhydrides and other polyesters, such as polycaprolactone (PCL) [37], have been shown to be possible alternatives as VEGF carriers. In recent years, different materials have been combined to modulate the mechanical and biological properties of the scaffold. To give an example, fibrin-based biomaterials have been found to stimulate and support the growth of new blood vessels, but their poor mechanical properties have encouraged researchers to combine them with synthetic materials. Losi et al [38] have obtained composite scaffolds made of a synthetic layer of poly(ether)urethanepolydimethylsiloxane, contributing to mechanical resistance, and a fibrin layer that acts as a GF delivery carrier.

Numerous preparation methods have been reported for manufacturing 3D porous scaffolds, namely fiber bonding, emulsion freeze drying, solvent casting/particulate leaching [37], high pressure processing, gas foaming/particulate leaching, thermally induced phase separation, electrospinning [39] and rapid prototyping (reviewed in [40]). Recently, injectable biomaterials that form scaffold in situ have been used. These can be administered parenterally, but also locally, with the advantage that the scaffold acquires the shape of the tissue defect and surgery is avoided. Recently, $\mathrm{Wu}$ et al [41], prepared a VEGF-conjugated injectable hydrogel that was intramyocardially injected into Sprague Dawley rat infarcted hearts, preserving ventricular function after myocardial ischemia by stabilizing the infarct and inducing angiogenesis. The gel was composed of a temperature sensitive aliphatic polyester (poly ( $\delta$-valerolactone)-block-ply (ethylene glycol)-block-poly ( $\delta$-valerolactone)). This polymer is called thermosensitive since it dissolves in water at room temperature, but gels at $37^{\circ} \mathrm{C}$ (see Fig. 1C). This property makes this kind of material especially interesting.

The route of administration to reach the infarcted heart still remains challenging (see Figure 2) [42]. When implanting a scaffold in the heart, surgery is necessary, with the consequent inconvenience and risks for the patient. The scaffold in that case needs to be placed covering the infarcted zone, or surrounding it, so that GFs are released towards the cells acting in the repair process and are responsive to VEGF (Fig. 1A). If an injectable gel is used, surgery may be avoided, since it can be directly injected into the heart without surgical intervention (Fig. 1C).

To optimize scaffold effectiveness, it can be surface modified. Collagen and gelatin are known to modulate adhesive properties. The attachment of a cell adhesive peptide on the surface improves ligand-receptor interaction, as well as cell adhesion. In a recent article, Porter et al [44] propose the preparation of a biomimetic hydrogel by including an adhesion peptide sequence derived from fibronectin (RGDS), in a VEGF covalently incorporated PEG hydrogel, to enhance cell adhesion. However, in this study only in vitro assays were performed. Hyaluronic acid (HA) is a substance present in the ECM that interacts with CD4 receptor, promoting wound healing, making its use attractive. Heparin modification has also been extensively studied for the release of GFs. Heparin is a highly sulfated glycosaminoglycan in the ECM, and is known for its specific interactions with various angiogenic GFs [61, 62]. A wide variety of scaffolds including nanofibers, prepared from collagen, fibrin, chitosan, alginate, PLA and PLGA, have been immobilized with heparin to achieve sustained release of GFs [40,63]. Based on this, Zieris et al [37, 45] prepared a biohybrid hydrogel with star-shaped PEG and carbodiimide/N-hydroxysulfosuccinimiede-activated heparin, obtaining appropriate VEGF binding and release, with good in vitro results (included in Table 2). On the other hand, Singh et al [37] demonstrated an enhanced VEGF angiogenic effect, in a subcutaneous implant model, when a PCL scaffold was surface 
modified with heparin.

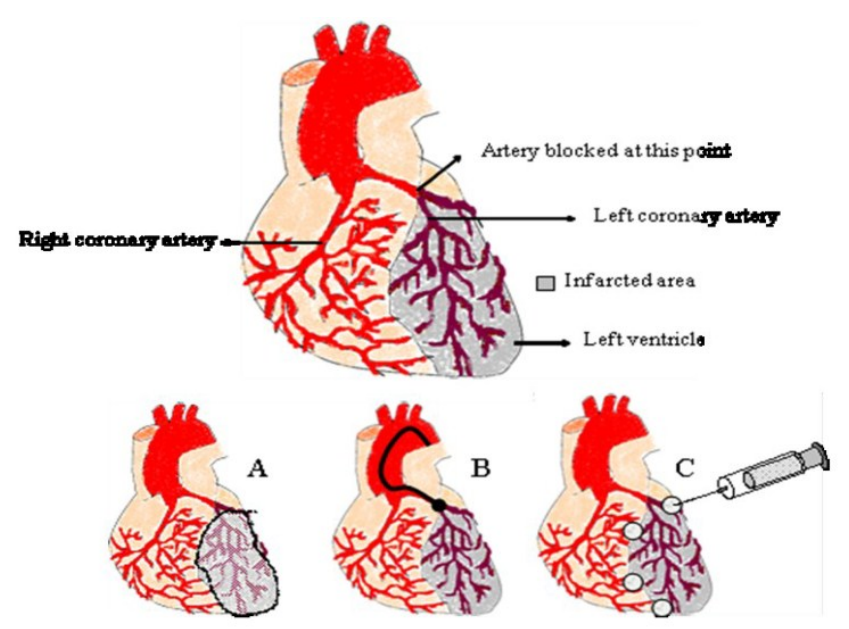

Figure 2. Depending on the VEGF carrier different routes of administration can be chosen. Solid scaffolds need to be attached to the heart, frequently covering the infarcted area (A). Particles can be injected in the desired zone intracoronarily using a catheter (B) or by direct injection (C). Injectable scaffolds can also be implanted using this route.

\section{Nano/Microparticles}

Among the particulated delivery systems MPs $(>1 \mu \mathrm{m}$ and $<1,000 \mu \mathrm{m}$ sized $)$ and NPs $(<1 \mu \mathrm{m}$ sized $)$ have been used for VEGF delivery. Microsized particles are not readily internalized by the cells, but they have the potential to provide sustained release kinetics after implantation. In addition, MP diffusion from the implantation site is infrequent, which avoids undesired effects in other tissues. Thus, MPs provide control over the release rate and dose, yielding desirable concentrations for a period of time [64]. On the other hand, NPs can penetrate through capillaries into the cell machinery. Therefore, the pro-angiogenic potential of GFs in NPs or MPs in the tissue is not necessary equivalent. In relation to drug distribution within the particle, we can distinguish between nano/microcapsules and nano/microspheres (see Fig. $1 \mathrm{~A}$ and $1 \mathrm{~B})$. A clear advantage of these DDS, when compared with scaffolds, is the route of administration. As it has been mentioned before, most of the scaffolds need to be implanted through a surgical intervention. In the case of the particles, they can be injected directly into the myocardium without surgery. Frequently, several injections are performed around the infarcted area, in the confluence of the healthy and the damaged tissue (see Fig. 2C). Another non-invasive route for these DDS is the intracoronary route via a catheter (see Fig. 2B).
To prepare these DDSs, numerous strategies have been employed, among others, solvent extraction/evaporation, spray drying and phase separation method [65]. Spray drying is associated with low process efficacy and protein denaturing due to dehydration [66]. The phase separation method is mediated by a solvent and coacervating agent that can react with the protein and disrupt the secondary structure. Moreover, this is a process that is not well suited to producing particles in the low micrometer size range [67]. The solvent extraction/evaporation method is thus thought to be, to date, the most appropriate. Two different modifications of this procedure are the single emulsion and the double emulsion solvent evaporation method. In the first one, since proteins are hydrophobic molecules, low encapsulation efficiency (EE) values are obtained. EE is an important feature and can be defined as the capability of immobilizing most of the protein added during the process. In the single emulsion case, protein is incorporated in the external phase of the emulsion $(\mathrm{o} / \underline{\mathrm{w}})$, whereas in the double emulsion the protein is localized in the internal aqueous phase $(\underline{w} / \mathrm{o} / \mathrm{w})$, diminishing the loss of the molecule. Nevertheless, this method presents some drawbacks, such as the need to reach high temperatures or to employ mechanical forces that can damage the protein. Systems to avoid elevated temperatures and stirring during the emulsion preparation have now been designed. An example is the Total Recirculation One Machine System ${ }^{\circledR}$ (TROMS) [68]. In the TROMS, the inner aqueous phase of the emulsion is injected into the organic phase. This blend is forced to circulate through a closed circuit with a specified inner diameter for a period of time. Once the first emulsion is formed, it is injected into the external aqueous phase leading, after a period of time in circulation, to the constitution of the double emulsion without inflicting too much stress on the protein so that bioactivity is preserved. Employing TROMS we have been able to encapsulate VEGF and other proteins in PLGA microparticles with EE values over $80 \%$ while maintaining protein bioactivity during the formulation process [54, 69]. On the other hand, the formation of aqueous/organic solvent interfaces is the main disadvantage of this method. Also, when using PLGA copolymer, hydrophobic interactions between the protein and PLGA are responsible for protein aggregation and denaturing. To minimize these effects, addition of human serum albumin (HSA) or surfactants such as poly ethylene glycol (PEG), helps to protect the protein by preventing hydrophobic contacts [70]. Another important factor to take into account is $\mathrm{pH}$ modification. When PLGA degrades, $\mathrm{pH}$ decreases due to the presence of 
glycolic and lactic acid [71], and this is associated with a loss of bioactivity as a consequence of protein aggregation and chemical degradation. It may also be possible that PLGA degradation products and proteins react, leading, for example, to protein acetylation [71]. Therefore approaches to reduce acid-induced damage have been discussed, such as incorporating $\mathrm{Mg}(\mathrm{OH}) 2$ in the formulation [72].

PLGA particles with VEGF have been studied extensively for ischemia tissue repair [52-54] and they appear to be a promising strategy. Guldberg et al [52] demonstrated a vigorous revascularization response when treating a hindlimb ischemia model in mice with VEGF-NPs, which was greater than the response obtained after $5 \mu \mathrm{g}$ VEGF, $2.5 \mu \mathrm{g}$ VEGF, and saline treatment. VEGF-MPs were also prepared by Baysal et al [53] to face therapeutic angiogenesis. In this study, MPs succeeded in promoting HUVEC proliferation and migration. Our group developed VEGF loaded PLGA MPs which, when intramyocardially injected in an infarcted heart rat model, improved vasculogenesis and tissue remodeling [54].

\section{Particles included in scaffolds}

More sophisticated systems can be prepared by incorporating protein loaded particles into scaffolds. These kinds of system present some features that can be of interest in some situations. Firstly, the release profile is modified (Fig. 3). In short, the burst effect is maintained while the sustained release of the protein is prolonged [64]. However, possibilities are unlimited, since the GF can be included both in the particles and in the scaffold, or just inside the particles. Also, GFs can be covalently immobilized in the carriers or non-covalently, leading to different delivery. Moreover, the scaffold architecture can modulate different release profiles, depending on whether it is a multilayered system or a core-shell system. All these alternatives, and others, have been recently reviewed by Chen et al [64].

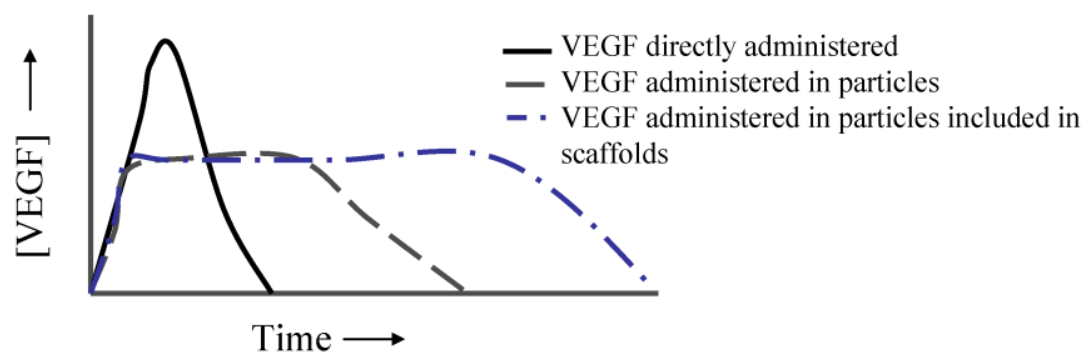

Figure 3. Simplification of how VEGF release profile can be modified when included in particles or in particles embedded in scaffolds.

An elegant construct has been described by Chung et al [51]. They compare the angiogenesis potential of VEGF when included in a fibrin gel or when included in a heparin-functionalized nanoparticle incorporated in the same fibrin gel. In the first case, almost $100 \%$ of VEGF was released within the first 3 days, whereas sustained release of the protein was observed for more than 30 days in the second approach, resulting in an enhanced angiogenic effect. Recently, des Rieux et al [57] investigated whether angiogenesis is enhanced when administering VEGF that is freely incorporated in two types of matrices (Matrigel ${ }^{\circledR}$ or PLGA) or when VEGF is previously encapsulated in dextran-chitosan nanoparticles. The results lead these authors to conclude that a more interesting approach could be to fill the PLGA scaffold pores with the hydrogel, both systems being loaded with VEGF nanoparticles, and thus combine three carrier systems.

\section{Combination of VEGF with other biomolecules}

When trying to regenerate heart tissue, the combination of several factors (pro-angiogenic, cardioprotective and chemoattracting) could be a good strategy [73]. As described above, a hypoxic stimulus in the heart activates not only VEGF and neo-vascularization, but complex and tightly spatio-temporally coordinated pathways, involving different cells and inter-regulated factors. DDSs appear in this context not only as the way to prolong the short half life of all these biomolecules, but also as a suitable platform to mimic the optimum environment for the tissue to regenerate, by delivering various GFs in a different but controlled manner. Work in this field has increased in recent years. VEGF has been incorporated into carriers together with other factors; the next step is to prepare systems that allow a dual or sequential delivery of factors with a tight dose control [46]. Recently Chapanian and Amsden [49] have been 
able to create a system for the combined and sequential delivery of VEGF and hepatocyte growth factor. The construct is composed of trimethylene carbonate based elastomers and is combined with an osmotic mechanism to release acid-sensitive GFs, preserving its bioavility. Another approach is the combination of VEGF with Angiopoietin-1, another GF implicated in vascular stabilization and remodeling [31]. These were covalently immobilized in collagen scaffolds and a chicken chorioallantoic membrane angiogenesis assay was performed to test the system. The results led these authors to conclude that scaffolds with co-immobilized VEGF and Ang1 further improved angiogenesis, as compared to independently immobilized VEGF or Ang1. Also, covalent immobilization of growth factors on the scaffolds yielded better results compared to simple addition of soluble growth factors to scaffolds (Table 2). Other factors combined with VEGF have been FGF-2 in PEG based hydrogels $[45,46]$, PDGF-BB in alginate hydrogels [74] and in HA/chitosan NPs [50], bFGF in a composite scaffold [38] and sphingosine 1-phosphate [43]. The work of Hao et al [74] is particularly worth mentioning. While the majority of the studies have just proved the ability of the system to incorporate GFs and to deliver them, in this case the system was applied to a myocardial infarction rat model, with the formation of more mature vessels and improvement of cardiac function when compared to delivery of single factors [17, 74]. Despite these results, it is still necessary to answer the question as to which the appropriate VEGF co-factor/s are and what the ideal release profile for each one is.

\section{Application of Drug delivery systems in the ischemic heart}

To sum up, it is possible to conclude that each delivery system has its own advantages and limitations. As mentioned before, the administration route is a key point to take into account. Several methods of delivery are used (Figure 2.) depending on the pathology of the patient. In the case of chronic myocardial ischemia, direct intramyocardial injection is preferred, since it allows delivery in the ischemic tissue with an occluded artery [75]. Direct intramyocardial injection can be trans-epicardial, trans-endocardial, and less frequently, trans-venous. The first is usually performed during open heart surgery, and due to the high risk, is not performed as a standalone procedure. Another context is an acute myocardial infarction, in which intracoronary injection is the most frequent method [76].

On balance, solid scaffolds present the disadvantage of needing to be implanted in the heart, making surgery mandatory. Solid scaffolds would therefore not be an adequate DDS to treat acute myocardial ischemia, or for chronic myocardial ischemia when the patient requires open heart surgery.

The administration route is not the only feature to be taken into account when choosing a DDS. For instance, scaffolds have the drawback of the administration route but they show the benefit of covering the total area of the infarct. In consequence, if they are built with materials able to reproduce the extracellular matrix, they can help the heart to overcome the consequences of the negative remodeling [77]. Furthermore, if the aim is to administer more than one factor with different release profiles, the scaffold elaboration process becomes more complicated, as it is necessary to include in it, for instance, particles that modify the release rate of one or more of the active molecules.

On the other hand, use of particles makes all the administration routes possible. It is also easier to combine different particles containing several factors, theoretically providing a more orchestrated signaling environment to the damage tissue.

In relation to the possibility of preparing an engineered construct including factors, DDS and cells, both scaffold and MPs are potentially useful, whereas the reduced area of NPs does not provide enough space to attach cells to their surface. Sustained release of the factors is also difficult to achieve when administering NPs, not to mention their greater likelihood of being removed from the tissue by phagocytic uptake.

Most of the published studies using VEGF loaded in DDSs carried out limited in vivo studies, and just a few of them have applied VEGF-DDS in the ischemic heart. Thus, it is still too soon to conclude which DDS is the most suitable to apply in cardiac repair.

Therefore, as all DDS present advantages and disadvantages, combining them to prepare more sophisticated constructs could make it possible to exploit the benefits of each one in order to give the optimal signals to the cardiac tissue that needs to regenerate.

\section{FUTURE DIRECTIONS: THE TISSUE ENGINEERING TRIAD}

As the same time as the number of papers in which GFs and DDSs are combined has increased, numerous researchers have focused on cell therapy to treat cardiac injury[42]. Just as DDSs appear in the first case as a suitable approach for prolonging the permanence of GFs in the tissue, the cell engraftment approach may well be extended by including cells in scaffolds. So far, these scaffolds have progressed to 
mimic the cell's natural environment as far as possible, aiding in its survival and development. In this sense, the incorporation of factors in the scaffold helps not only to modulate cell life, but also acts in the tissue and improves its recovery. The combination of engineered platforms, cells and GFs has been named the tissue engineering triad, and seems to be a promising tool in the field of cardiac repair. A considerable research effort is now needed to establish the "winning combination".

\section{Acknowledgments}

We gratefully acknowledge support from the Spanish Ministry of Science and Innovation PSE SINBAD (PSS 0100000-2008-1), Caja Navarra Foundation (Programa Tu Eliges: Tu Decides), Spanish Ministry of Sciences and Education and Agencia Española de Cooperación Internacional para el Desarrollo (AECID).

\section{Competing Interests}

The authors have declared that no competing interest exists.

\section{References}

1. Ferrara N, Henzel WJ. Pituitary follicular cells secrete a novel heparin-binding growth factor specific for vascular endothelial cells. Biochem Biophys Res Commun. 1989; 161: 851-8.

2. Leung DW, Cachianes G, Kuang WJ, Goeddel DV, Ferrara N. Vascular endothelial growth factor is a secreted angiogenic mitogen. Science. 1989; 246: 1306-9.

3. Keck PJ, Hauser SD, Krivi G, Sanzo K, Warren T, Feder J, et al. Vascular permeability factor, an endothelial cell mitogen related to PDGF. Science. 1989; 246: 1309-12.

4. Senger DR, Galli SJ, Dvorak AM, Perruzzi CA, Harvey VS, Dvorak HF. Tumor cells secrete a vascular permeability factor that promotes accumulation of ascites fluid. Science. 1983; 219: 983-5.

5. Patil AS, Sable RB, Kothari RM. Occurrence, biochemical profile of vascular endothelial growth factor (VEGF) isoforms and their functions in endochondral ossification. J Cell Physiol. 2012; 227: 1298-1308.

6. Vempati P, Popel AS, Mac Gabhann F. Formation of VEGF isoform-specific spatial distributions governing angiogenesis: computational analysis. BMC Syst Biol. 2011; 5: 59.

7. Grunewald FS, Prota AE, Giese A, Ballmer-Hofer K. Structure-function analysis of VEGF receptor activation and the role of coreceptors in angiogenic signaling. Biochim Biophys Acta. 2009; 1804: 567-80.

8. Folkman J. Tumor angiogenesis: therapeutic implications. N Engl J Med. 1971; 285: 1182-6.

9. Kim KJ, Li B, Winer J, Armanini M, Gillett N, Phillips HS, et al. Inhibition of vascular endothelial growth factor-induced angiogenesis suppresses tumour growth in vivo. Nature. 1993; 362: 841-4.

10. Ferrara N, Hillan KJ, Gerber HP, Novotny W. Discovery and development of bevacizumab, an anti-VEGF antibody for treating cancer. Nat Rev Drug Discov. 2004; 3: 391-400.

11. Hahn O, Stadler W. Sorafenib. Curr Opin Oncol. 2006; 18: 615-21.

12. Rock EP, Goodman V, Jiang JX, Mahjoob K, Verbois SL, Morse D, et al. Food and Drug Administration drug approval summary: Sunitinib malate for the treatment of gastrointestinal stromal tumor and advanced renal cell carcinoma. Oncologist. 2007; 12: 107-13.

13. Smart N, Dube KN, Riley PR. Coronary vessel development and insight towards neovascular therapy. Int J Exp Pathol. 2009; 90: 262-83.

14. Carmeliet P, Jain RK. Molecular mechanisms and clinical applications of angiogenesis. Nature. 2011; 473: 298-307.

15. Riley PR, Smart N. Vascularizing the heart. Cardiovasc Res. 2011; 91: 260-8.
16. Gibson C, Laham R, Giordano F. Magnitude and location of new angiographically apparent coronary collaterals following intravenous VEGF administration. J Am Coll Cardio. 1999; 1999: 65A.

17. Hendel RC, Henry TD, Rocha-Singh K, Isner JM, Kereiakes DJ, Giordano FJ, et al. Effect of intracoronary recombinant human vascular endothelial growth factor on myocardial perfusion: evidence for a dose-dependent effect. Circulation. 2000; 101: 118-21.

18. Eppler SM, Combs DL, Henry TD, Lopez JJ, Ellis SG, Yi JH, et al. A target-mediated model to describe the pharmacokinetics and hemodynamic effects of recombinant human vascular endothelial growth factor in humans. Clin Pharmacol Ther. 2002; 72: 20-32.

19. Henry TD, Rocha-Singh K, Isner JM, Kereiakes DJ, Giordano FJ, Simons $\mathrm{M}$, et al. Intracoronary administration of recombinant human vascular endothelial growth factor to patients with coronary artery disease. Am Heart J. 2001; 142: 872-80.

20. Henry TD, Annex BH, McKendall GR, Azrin MA, Lopez JJ, Giordano FJ, et al. The VIVA trial: Vascular endothelial growth factor in Ischemia for Vascular Angiogenesis. Circulation. 2003; 107: 1359-65.

21. Sato K, Wu T, Laham RJ, Johnson RB, Douglas P, Li J, et al. Efficacy of intracoronary or intravenous VEGF165 in a pig model of chronic myocardial ischemia. J Am Coll Cardiol. 2001; 37: 616-23.

22. Cleland JL, Duenas ET, Park A, Daugherty A, Kahn J, Kowalski J, et al. Development of poly-(D,L-lactide--coglycolide) microsphere formulations containing recombinant human vascular endothelial growth factor to promote local angiogenesis. J Control Release. 2001; 72: 13-24.

23. Grdisa M. The delivery of biologically active (therapeutic) peptides and proteins into cells. Curr Med Chem. 2011; 18: 1373-9.

24. Roncalli J, Tongers J, Losordo DW. Update on gene therapy for myocardial ischaemia and left ventricular systolic dysfunction or heart failure. Arch Cardiovasc Dis. 2010; 103: 469-76.

25. Njeim MT, Hajjar RJ. Gene therapy for heart failure. Arch Cardiovasc Dis. 2010; 103: 477-85.

26. Zachary I, Morgan RD. Therapeutic angiogenesis for cardiovascular disease: biological context, challenges, prospects. Heart. 2011; 97: 181-9.

27. Hinkel R, Trenkwalder T, Kupatt C. Gene therapy for ischemic heart disease. Expert Opin Biol Ther. 2011; 11: 723-37.

28. Jawad H, Lyon AR, Harding SE, Ali NN, Boccaccini AR. Myocardial tissue engineering. Br Med Bull. 2008; 87: 31-47.

29. Bhatia SK. Tissue engineering for clinical applications. Biotechnol J. 2010; 5: 1309-23.

30. Chew SY, Low WC. Scaffold-based approach to direct stem cell neural and cardiovascular differentiation: an analysis of physical and biochemical effects. J Biomed Mater Res A. 2011; 97: 355-74.

31. Chiu LL, Radisic M. Scaffolds with covalently immobilized VEGF and Angiopoietin-1 for vascularization of engineered tissues. Biomaterials. 2010; 31: 226-41.

32. Miyagi Y, Chiu LL, Cimini M, Weisel RD, Radisic M, Li RK. Biodegradable collagen patch with covalently immobilized VEGF for myocardial repair. Biomaterials. 2011; 32: 1280-90.

33. Zhang P, Wu H, Wu H, Lu Z, Deng C, Hong Z, et al. RGD-conjugated copolymer incorporated into composite of poly(lactide-co-glycotide) and poly(L-lactide)-grafted nanohydroxyapatite for bone tissue engineering. Biomacromolecules. 2011; 12: 2667-80.

34. Toyokawa N, Fujioka H, Kokubu T, Nagura I, Inui A, Sakata R, et al. Electrospun synthetic polymer scaffold for cartilage repair without cultured cells in an animal model. Arthroscopy. 2010; 26: 375-83.

35. Xue C, Hu N, Gu Y, Yang Y, Liu Y, Liu J, et al. Joint Use of a Chitosan/PLGA Scaffold and MSCs to Bridge an Extra Large Gap in Dog Sciatic Nerve. Neurorehabil Neural Repair. 2012 Jan;26(1):96-106.

36. Lu JM, Wang X, Marin-Muller C, Wang H, Lin PH, Yao Q, et al. Current advances in research and clinical applications of PLGA-based nanotechnology. Expert Rev Mol Diagn. 2009; 9: 325-41.

37. Singh S, Wu BM, Dunn JC. The enhancement of VEGF-mediated angiogenesis by polycaprolactone scaffolds with surface cross-linked heparin. Biomaterials. 2011; 32: 2059-69.

38. Losi P, Briganti E, Magera A, Spiller D, Ristori C, Battolla B, et al. Tissue response to poly(ether)urethane-polydimethylsiloxane-fibrin composite scaffolds for controlled delivery of pro-angiogenic growth factors. Biomaterials. 2010; 31: 5336-44.

39. Ayres CE, Jha BS, Sell SA, Bowlin GL, Simpson DG. Nanotechnology in the design of soft tissue scaffolds: innovations in structure and function. Wiley Interdiscip Rev Nanomed Nanobiotechnol. 2010; 2: 20-34.

40. Gaikwad V, Patil A, Gaikwad M. Scaffolds for Drug Delivery in Tissue Engineering. International Journal of Pharmaceutical Sciences and Nanotechnology. 2008; 1: 113-22. 
41. Wu J, Zeng F, Huang XP, Chung JC, Konecny F, Weisel RD, et al. Infarct stabilization and cardiac repair with a VEGF-conjugated, injectable hydrogel. Biomaterials. 2011; 32: 579-86.

42. Wu KH, Han ZC, Mo XM, Zhou B. Cell delivery in cardiac regenerative therapy. Ageing Res Rev. 2012 Jan;11(1):32-40.

43. Tengood JE, Kovach KM, Vescovi PE, Russell AJ, Little SR. Sequential delivery of vascular endothelial growth factor and sphingosine 1-phosphate for angiogenesis. Biomaterials. 2010; 31: 7805-12.

44. Porter AM, Klinge CM, Gobin AS. Biomimetic hydrogels with VEGF induce angiogenic processes in both hUVEC and hMEC. Biomacromolecules. 2011; 12: 242-6.

45. Zieris A, Prokoph S, Levental KR, Welzel PB, Grimmer M, Freudenberg $\mathrm{U}$, et al. FGF-2 and VEGF functionalization of starPEG-heparin hydrogels to modulate biomolecular and physical cues of angiogenesis. Biomaterials. 2010; 31: 7985-94.

46. Zieris A, Chwalek K, Prokoph S, Levental KR, Welzel PB, Freudenberg $\mathrm{U}$, et al. Dual independent delivery of pro-angiogenic growth factors from starPEG-heparin hydrogels. J Control Release. 2011;156(1):28-36.

47. Silva EA, Mooney DJ. Effects of VEGF temporal and spatial presentation on angiogenesis. Biomaterials. 2010; 31: 1235-41.

48. Jia X, Zhao C, Li P, Zhang H, Huang Y, Li H, et al. Sustained Release of VEGF by Coaxial Electrospun Dextran/PLGA Fibrous Membranes in Vascular Tissue Engineering. J Biomater Sci Polym Ed. 2010; 22: 1811-27.

49. Chapanian R, Amsden BG. Combined and sequential delivery of bioactive VEGF165 and HGF from poly(trimethylene carbonate) based photo-cross-linked elastomers. J Control Release. 2010; 143: 53-63.

50. Parajo Y, D'Angelo I, Welle A, Garcia-Fuentes M, Alonso MJ. Hyaluronic acid/Chitosan nanoparticles as delivery vehicles for VEGF and PDGF-BB. Drug Deliv. 2010; 17: 596-604.

51. Chung YI, Kim SK, Lee YK, Park SJ, Cho KO, Yuk SH, et al. Efficient revascularization by VEGF administration via heparin-functionalized nanoparticle-fibrin complex. J Control Release. 2010; 143: 282-9.

52. Golub JS, Kim YT, Duvall CL, Bellamkonda RV, Gupta D, Lin AS, et al. Sustained VEGF delivery via PLGA nanoparticles promotes vascular growth. Am J Physiol Heart Circ Physiol. 2010; 298: H1959-65.

53. Karal-Yilmaz O, Serhatli M, Baysal K, Baysal BM. Preparation and in vitro characterization of vascular endothelial growth factor (VEGF)-loaded poly(D,L-lactic-co-glycolic acid) microspheres using a double emulsion/solvent evaporation technique. J Microencapsul. 2011; 28: $46-54$

54. Formiga FR, Pelacho B, Garbayo E, Abizanda G, Gavira JJ, Simon-Yarza $\mathrm{T}$, et al. Sustained release of VEGF through PLGA microparticles improves vasculogenesis and tissue remodeling in an acute myocardial ischemia-reperfusion model. J Control Release. 2010; 147: 30-7.

55. Nagai N, Kumasaka N, Kawashima T, Kaji H, Nishizawa M, Abe T. Preparation and characterization of collagen microspheres for sustained release of VEGF. J Mater Sci Mater Med. 2010; 21: 1891-8.

56. Daugherty AL, Rangell LK, Eckert R, Zavala-Solorio J, Peale F, Mrsny RJ. Sustained release formulations of rhVEGF produce a durable response in a murine model of peripheral angiogenesis. Eur J Pharm Biopharm. 2011; 78: 289-97.

57. des Rieux A, Ucakar B, Mupendwa BP, Colau D, Feron O, Carmeliet P, et al. 3D systems delivering VEGF to promote angiogenesis for tissue engineering. J Control Release. 2011; 150: 272-8.

58. Jay SM, Shepherd BR, Andrejecsk JW, Kyriakides TR, Pober JS, Saltzman WM. Dual delivery of VEGF and MCP-1 to support endothelial cell transplantation for therapeutic vascularization. Biomaterials. 2010; 31: 3054-62.

59. Amsden BG, Timbart L, Marecak D, Chapanian R, Tse MY, Pang SC. VEGF-induced angiogenesis following localized delivery via injectable, low viscosity poly(trimethylene carbonate). J Control Release. 2010; 145: 109-15.

60. Gao J, Liu J, Gao Y, Wang C, Zhao Y, Chen B, et al. A Myocardial Patch Made of Collagen Membranes Loaded with Collagen-Binding Human Vascular Endothelial Growth Factor Accelerates Healing of the Injured Rabbit Heart. Tissue Eng Part A. 2011 Nov;17:2739-47.

61. Padera R, Venkataraman G, Berry D, Godavarti R, Sasisekharan R. FGF-2/fibroblast growth factor receptor/heparin-like glycosaminoglycan interactions: a compensation model for FGF-2 signaling. Faseb J. 1999; 13: 1677-87.

62. Springer BA, Pantoliano MW, Barbera FA, Gunyuzlu PL, Thompson LD, Herblin WF, et al. Identification and concerted function of two receptor binding surfaces on basic fibroblast growth factor required for mitogenesis. J Biol Chem. 1994; 269: 26879-84.

63. Wissink MJ, Beernink R, Poot AA, Engbers GH, Beugeling T, van Aken WG, et al. Improved endothelialization of vascular grafts by local release of growth factor from heparinized collagen matrices. J Control Release. 2000; 64: 103-14.

64. Chen FM, Zhang M, Wu ZF. Toward delivery of multiple growth factors in tissue engineering. Biomaterials. 2010; 31: 6279-308.

65. Tamilvanan S, Venkatesh Babu R, Kannan K, Basu SK, Sa B. Manufacturing techniques and excipients used during the design of biodegradable polymer-based microspheres containing therapeutic peptide/protein for parenteral controlled drug delivery. PDA J Pharm Sci Technol. 2008; 62: 125-54.

66. Sollohub K, Cal K. Spray drying technique: II. Current applications in pharmaceutical technology. J Pharm Sci. 2010; 99: 587-97.

67. Vasita R, Katti D. Microparticle-Based Growth Factor Delivery Systems in Tissue Engineering. In: Ravi KM, editor. Handbook of particulated drug delivery. Stevenson Ranch: American Scientific Publishers. 2008: 291-310.

68. del Barrio GG, Novo FJ, Irache JM. Loading of plasmid DNA into PLGA microparticles using TROMS (Total Recirculation One-Machine System): evaluation of its integrity and controlled release properties. J Control Release. 2003; 86: 123-30.

69. Garbayo E, Ansorena E, Lanciego JL, Aymerich MS, Blanco-Prieto MJ. Sustained release of bioactive glycosylated glial cell-line derived neurotrophic factor from biodegradable polymeric microspheres. Eur J Pharm Biopharm. 2008; 69: 844-51.

70. Kratz F. Albumin as a drug carrier: design of prodrugs, drug conjugates and nanoparticles. J Control Release. 2008; 132: 171-83.

71. Houchin ML, Topp EM. Chemical degradation of peptides and proteins in PLGA: a review of reactions and mechanisms. J Pharm Sci. 2008; 97: 2395-404.

72. Schwendeman SP. Recent advances in the stabilization of proteins encapsulated in injectable PLGA delivery systems. Crit Rev Ther Drug Carrier Syst. 2002; 19: 73-98.

73. Beohar N, Rapp J, Pandya S, Losordo DW. Rebuilding the damaged heart: the potential of cytokines and growth factors in the treatment of ischemic heart disease. J Am Coll Cardiol. 2010; 56: 1287-97.

74. Hao X, Silva EA, Mansson-Broberg A, Grinnemo KH, Siddiqui AJ, Dellgren G, et al. Angiogenic effects of sequential release of VEGF-A165 and PDGF-BB with alginate hydrogels after myocardial infarction. Cardiovasc Res. 2007; 75: 178-85.

75. van Ramshorst J, Rodrigo SF, Schalij MJ, Beeres SL, Bax JJ, Atsma DE. Bone marrow cell injection for chronic myocardial ischemia: the past and the future. J Cardiovasc Transl Res. 2011; 4: 182-91.

76. Dib N, Khawaja H, Varner S, McCarthy M, Campbell A. Cell therapy for cardiovascular disease: a comparison of methods of delivery. J Cardiovasc Transl Res. 2011; 4: 177-81.

77. Cristallini C, Gagliardi M, Barbani N, Giannessi D, Guerra GD. Novel biodegradable, biomimetic and functionalised polymer scaffolds to prevent expansion of post-infarct left ventricular remodelling. J Mater Sci Mater Med. 2012 Jan;23(1):205-16. 